\title{
CORPORATE BRAND IDENTITY CO-CREATION \\ IN BUSINESS-TO-BUSINESS CONTEXTS
}

\begin{abstract}
Traditionally, corporate brand identity was considered to be directed and controlled by managers. However, more recent research has begun to recognize the limits of this view, which has led to the emergence of a stakeholder-driven, dynamic perspective, in which multiple stakeholders co-create diverse corporate brand meanings. This perspective argues that while managers have influence over the essence of the corporate brand, other stakeholders imprint and share their own interpretations. To better understand the process of corporate brand identity co-creation, we used a case study method with multiple cases, involving five small and medium sized business-to-business (B2B) corporate brands. We specifically chose B2B corporate brands, because they are often built on long-term and close relationships with diverse stakeholders, serving as a solid ground for illustrating the process of co-creation. To obtain the necessary depth of insight, we conducted 37 semi-structured interviews. Our research shows that corporate brand identity co-creation in B2B contexts is an ongoing dynamic process where multiple internal and external stakeholders engage in four different but interrelated performances: communicating; internalizing; contesting; and elucidating.
\end{abstract}

\section{Keywords}

Corporate brand identity; co-creation; stakeholder performances; multiple case study; qualitative research. 


\section{Introduction}

Corporate brands have become increasingly prominent in the brand management literature (e.g., de Roeck, Maon, \& Lejeune, 2013; Ind, Iglesias, \& Schultz, 2013) and have fueled, what Merz, He, and Vargo (2009) call, the stakeholder-focus brand era. This reflects the key difference between product and corporate brands, in that while product brands focus on customers, corporate brands have a wider scope (Roper \& Davies, 2007) and include multiple stakeholders (Balmer, 1995; Hatch \& Schultz, 2002), such as customers, employees, suppliers, media, investors, and society (Morsing \& Kristensen, 2002; Schultz, Antorini, \& Csaba, 2005).

While the branding literature has mainly concentrated on business-to-consumer (B2C) contexts and product brands (Merrilees, 2007), there is an emerging body of research, which highlights the benefits corporate brands can provide in business-to-business (B2B) contexts (e.g., Beverland, Napoli, \& Lindgreen, 2007; Mudambi, 2002). A strong B2B corporate brand confers uniqueness and credibility (Michell, King, \& Reast, 2001), supports premium prices (Low \& Blois, 2002), creates more enduring and profitable business relationships (Abimbola \& Kocak, 2007; Wong \& Merrilees, 2005), and influences the creation of desired positions in the market (Koporcic \& Halinen, 2018). It also benefits B2B customers by affecting decisionmaking processes (Bendixen, Bukasa, \& Abratt, 2004), increasing customer confidence in the purchase decision (Low \& Blois, 2002), and reducing customer perceived risk (Bengtsson \& Servais, 2005; Mudambi, 2002; Ohnemus, 2009).

The main element of a corporate brand is its identity. The corporate brand identity is what makes a corporate brand unique and relevant to its stakeholders, when compared to the competition (Kapferer, 2008). In essence, corporate brand identity is what creates differentiation (de Chernatony, 1999) and allows B2B organizations to reinforce their competitive advantage (Beverland et al., 2007). The traditional view sees corporate brand 
identity as stable and unilaterally determined by managers and other internal stakeholders (Essamri et al., 2019; Kapferer, 2012). It is how internal stakeholders "perceive their company and how they aim to present it to the outside world" (Koporcic \& Halinen, 2018, p. 395). This view sees corporate brand image as the perceptions that different audiences (e.g., customers, media, investors) associate with a specific corporate brand (i.e., brand or customer associations) (e.g., Anselmsson et al., 2014; Cho and Fiore, 2015; Keller, 1993) and is typically focused on the external audiences of an organization (e.g., Cho and Fiore, 2015; Iglesias, Markovic, Singh, \& Sierra, 2019).

In contrast, an emerging literature stream in the field of brand management is challenging traditional approaches to identity and image (e.g., Da Silveira et al., 2013; Iglesias et al., 2013; von Wallpach et al., 2017a). This stream argues that corporate brand identity is not stable and is not solely determined by internal stakeholders. As Wallpach et al. (2017a, p. 444) argue "a distinction between an internal and external locus of identity construction becomes obsolete as stakeholders' brand-related activities transcend company borders." The emerging stream reflects the increasing permeability of organizations, where both internal and external stakeholders are involved in the corporate brand identity cocreation process. This is the perspective we adopt in this paper and we argue that corporate brand image are the perceptions that not only external stakeholders have about the corporate brand, but also the internal ones (e.g., an employee can have a perception of the corporate brand he/she works at).

Thus, we challenge the traditional view of corporate brand identity as determined by managers and other internal stakeholders, and fully controlled by them (e.g., Balmer, 1995; Balmer \& Grey, 2003; Kapferer, 2012). Instead, we recognize that the rapid growth of social media and online brand communities has created the opportunity for greater stakeholder interaction and involvement (Muniz \& O’Guinn, 2001). This has fostered a new perspective, 
which considers corporate brand identity to be a set of fluid, dynamic, and polysemous meanings, co-created by multiple internal and external stakeholders (e.g., Csaba \& Bengtsson, 2006; da Silveira, Lages, \& Simões, 2013; Iglesias, Ind, \& Alfaro, 2013; Koporcic and Halinen, 2018; Lucarelli \& Hallin, 2014; Michel, 2017; Vallaster \& von Wallpach, 2013; von Wallpach et al., 2017a). Brand meanings are the stakeholders' subjective re-interpretations of the corporate brand identity (Michel, 2017; von Wallpach et al., 2017a). They are "always in circulation and flux" (Batey, 2015, p. 104), and subject to constant negotiation, contestation, and discussion by multiple stakeholders (Iglesias and Bonet, 2012; Merz et al., 2009). This paradigm shift demands a deeper understanding of how corporate brand identity co-creation takes place, from a multi-stakeholder perspective. The multi-stakeholder view is particularly applicable to B2B contexts, because B2B corporate brands are more relational and interactional in nature than $\mathrm{B} 2 \mathrm{C}$ corporate brands (Markovic, Iglesias, Singh, \& Sierra, 2018; Webster \& Keller, 2004). B2B corporate brands also involve more cooperative long-term interactions among diverse stakeholders, and thus provide a solid ground for corporate brand identity co-creation. In this paper, co-creation is understood as a process that unfolds over time through a series of interactions that take place between multiple internal and external stakeholders (Iglesias et al., 2013; Ind, Iglesias, \& Markovic, 2017).

To contribute to the theoretical development of this emerging perspective, this study aims to investigate how corporate brand identity is co-created by multiple internal and external stakeholders in the B2B context. Notably, this implies a performativity approach (Butler, 2010; Goffman, 1959) to corporate brand identity co-creation. The rationale for this is that co-creation of identity is something stakeholders "perform" (Goffman, 1959, p. 15). In this regard, this study also aims to understand which stakeholder performances co-create the corporate brand identity. In order to study the corporate brand identity co-creation process, 
this research relies on a case study method with multiple cases. The five cases conducted focus on small and medium sized B2B corporate brands, and we adopt a balanced view of the multiple stakeholders (founders, managers, employees, customers and other external stakeholders) who have consistently participated over time in the co-creation of corporate brand identity (Rode \& Vallaster, 2005). The data were collected by conducting 37 semistructured, narrative interviews (Polkinghorne, 2007). The findings show how corporate brand identity stems from the founders and reflects their personal values, but develops over time in an ongoing process of adaptive change, co-created by the stakeholders' engagement in four different but interrelated performances: communicating; internalizing; contesting; and elucidating. This implies a role for managers as "conductors" (Michel, 2017) who reconcile the diverse stakeholder perspectives with a humble, open, and empathic leadership style. This study, therefore, contributes to the theoretical advancement of the brand management field, by describing how the corporate brand identity co-creation process takes place in $\mathrm{B} 2 \mathrm{~B}$ settings. More specifically, our study identifies and describes four categories of performances enacted by stakeholders that co-create corporate brand identity: communicating, internalizing, contesting, and elucidating. Finally, our study contributes to managerial awareness that corporate brand identity is organic, co-created by multiple stakeholders, and in constant flux.

The remainder of the paper is structured as follows. First, the theoretical background is presented, by elaborating on the traditional and emerging perspectives of corporate brand identity. Here, we present studies on corporate brand identity co-creation, from both B2C and B2B contexts, in order to build the foundation for our contributions. Second, we elaborate on the research gap and objectives of our study. Third, we describe the methodological approach, and data collection and analysis procedures. Fourth, we present our findings, focusing on different stakeholder performances. Finally, we provide a discussion and 
conclusion, comprising the theoretical contributions, managerial implications, limitations and future research directions.

\section{Theoretical background}

\subsection{Traditional perspectives on corporate brand identity}

Traditionally, corporate brand identity was seen as a unique set of stable associations, attributes or values, determined by managers to describe what a corporate brand stands for (Balmer \& Grey, 2003; de Chernatony, 1996; Keller, 1993). It was viewed as a managerial creation (Kapferer, 2012) defined by organizational behavior (Aaker, 1996; de Chernatony, 1996). In this traditional inside-out perspective, managers unilaterally determined and communicated the corporate brand identity (de Chernatony, 1996; Kapferer, 2012). Managers also "aspired" to maintain the corporate brand identity as consistent and stable over time (Aaker, 1996, p. 68). This resistance to change (da Silveira et al., 2013) helped to preserve the corporate brand role as a stable reference for customers (Kapferer, 2012) and employees (de Chernatony, 1996). Consequently, managers were perceived as custodians (Kapferer, 2012) or guardians (Michel, 2017) of the corporate brand identity.

Overall, the traditional perspective on corporate brand identity is characterized by: (1) a belief that it emanates unilaterally and top-down from the organization's management; and (2) stability over time (da Silveira et al., 2013).

\subsection{The emerging dynamic and multi-stakeholder perspective on corporate brand identity}

In contrast to the traditional approach, there is an emerging, and increasingly influential perspective, which considers corporate brand identity to be subject to a co-creation process in which multiple internal and external stakeholders take part (e.g., Chang, Wang, \& Arnett, 2018; da Silveira et al., 2013; Iglesias et al., 2013; Koporcic \& Halinen, 2018; 
Kornum, Gyrd-Jones, Al Zagir, \& Brandis, 2017; von Wallpach et al., 2017a,b). A process is defined as "a sequence of events or activities that describes how things change over time, or that represents an underlying pattern of cognitive transitions by an entity in dealing with an issue" (Van de Ven, 1992, p. 170). From this perspective, corporate brand identity is not unilaterally determined by managers and "does not represent the essence or the true substance of a brand, but refers to a multiplicity of meanings that multiple stakeholders reflexively constitute, negotiate, and eventually contest" (von Wallpach et al., 2017a, p. 444).

Core values are a central aspect of the identity of a corporate brand, and they generally stem from the brand's origin and founders (Urde, 2003). However, over time, corporate brand identity, and its core values, are co-created by multiple stakeholders in an organic way, potentially in different directions to the one intended by founders (Iglesias et al., 2013). Thus, the corporate brand identity is unstable, fluid (Csaba \& Bengtsson, 2006), and constantly changing through an "evolving symbiotic relationship" between managers, employees, and a set of external stakeholders (Ind, 2009, p. 10). This perspective on corporate brand identity aligns with the organizational studies literature that sees identity as a relational construct that is continuously and socially constructed (Hatch \& Schultz, 2002), and that arises out of multiple stakeholder interactions (e.g., Albert \& Whetten, 1985; Chang et al., 2018; Gioia, 1998). In the words of Hatch and Schultz (2002, p. 1004), "identity is not an aggregation of perceptions of an organization resting in peoples' heads, it is a dynamic set of processes by which an organization's self is continuously socially constructed from the interchange between internal and external definitions of the organization offered by all organizational stakeholders who join in the dance."

The present study, while acknowledging the key role of organizational founders, seeks to examine corporate brand identity as a temporary outcome of a dynamic and multistakeholder co-creation process. In so doing, it aligns with the perspective that various other 
stakeholders are also involved in the co-creation of corporate brand identity. Next, we elaborate on this in more detail.

\subsection{Corporate brand identity co-creation}

Even if the branding literature increasingly adheres to the emerging dynamic perspective on corporate brand identity, there is still scant research on how corporate brand identity is co-created by multiple stakeholders.

Among this scant research, there is one empirical study by Kornum et al. (2017), which compares the identity articulated by the Nike management team with the identity of Nike perceived by an online brand community. Here, the researchers identify a "nested system of identities" that creates both synergy and tension. The community accepts and supports Nike's identity, but at the same time develops its own set of brand-related values.

In another empirical study, von Wallpach et al. (2017a) investigate, from a multistakeholder approach, the performative identity co-construction of the LEGO brand. The research builds on Goffman's thesis $(1959$, p. 15) that identity is a performance, understood as "all the activity of a given participant on a given occasion, which serves to influence in any way the other participants." From this performativity perspective (see also Austin, 1975; Butler, 2010), identity is something that one "does" or "performs" (Goffman, 1959, 1967), instead of something that one "has." This suggests that corporate brand identity is not unilaterally constructed by managers, but emerges through a dynamic series of performative co-constructions involving a multiplicity of stakeholders (Butler, 2010). Von Wallpach et al.'s (2017a) study identified "seven types of LEGO-related identity performances" (von Wallpach et al., 2017a, p. 447) which alter LEGO's identity in different ways: (1) playing and liking; (2) basement building and showcasing; (3) creating and innovating; (4) community building and facilitating; (5) brand storytelling; (6) missionizing; and (7) 
marketplace developing. Von Wallpach et al. (2017a) also show how LEGO's identity construction is closely intertwined with the identity construction of the participating stakeholders.

Finally, based on an ethnographic study of the "Yes Scotland" campaign, Black and Veloutsou (2017) explore identity co-creation among three different entities: the brand; the brand community; and individual consumers. They show that the "Yes Scotland" brand was co-created through a dynamic social process with multiple stakeholder interactions. In addition, they find that these interactions among stakeholders also influence the co-creation of stakeholders' own identities.

Notably, the three above-mentioned studies are conducted in B2C contexts.

\subsection{Corporate brand identity co-creation in B2B contexts}

To the best of our knowledge, there are only three articles in B2B contexts that deal with the corporate brand identity co-creation process.

The first study, conducted by Mälaskä, Saraniemi and Tähtinen (2011), does not explicitly refer to corporate brand identity, but to the evolution of corporate brand meaning, and explores how network actors (i.e., stakeholders) take part in branding activities in the context of small and medium-sized enterprises (SMEs). The results highlight that "network actors participate in B2B branding" through direct and indirect actions (Mäläskä et al., 2011, p. 1149). "The direct actions influence branding separately from the company-governed branding process" (Mäläskä et al., 2011, p. 1149). Some examples of these actions are the word-of-mouth and co-promotion performed by the corporate brand network. The indirect actions are the network's attempts to give feedback to managers and to influence the managerial decision-making process. Overall, the internal and external stakeholder 
participation influences the corporate branding of the SME and the creation and development of its identity.

The second study, developed by Koporcic and Halinen (2018), presents the conceptualization of Interactive Network Branding (INB), as a process of corporate identity and reputation co-creation. INB is a result of interpersonal interactions between firms' representatives, thus being a dynamic and socially constructed process that leads to the creation of B2B corporate brands.

The third study, conducted by Törmälä and Gyrd-Jones (2017), is the only study that specifically aims to understand how corporate brand identity emerges as a "mutually influencing social process between a company and its key stakeholders" (Törmälä \& GyrdJones, 2017, p. 82). Törmälä and Gyrd Jones (2017, p. 79) use a narrative and performativity approach to identify "four sequential, yet partially overlapping, phases in the development of corporate brand identity." Their framework specifies the internal and external contextual factors in the case study, as well as the key activities performed by stakeholders that influence the corporate brand identity development of the new venture. They observe that, during the early years of the new venture, the corporate brand identity is unclear and erratic. In the absence of a well-articulated corporate brand identity, the corporate values mainly reflect the values of the founders. However, as the company grows, a new corporate brand identity emerges, is clarified and progressively adjusted through an iterative co-creative process influenced by multiple internal and external stakeholders.

\section{Research objectives}

The above-presented recent studies reflect a shift in brand thinking and signal a move to a dynamic and multi-stakeholder perspective on corporate brand identity, and how it is cocreated (Biraghi \& Gambetti, 2015; Merz et al., 2009). However, to better comprehend the 
corporate brand identity co-creation process, there needs to be more research conducted from a multi-stakeholder perspective (von Wallpach et al., 2017a). "Theory building must move from being organization-centered to being relationship-centered, in other words to consider the network of relationships that organizations are embedded in as core parts of their identities rather than as external elements" (Mäläskä et al., 2011, p. 1144).

To explore how corporate brand identity is co-created, this study adheres to a performative identity co-creation perspective that derives from Goffman $(1959,1967)$, and that was also previously used in the branding domain by da Silveira et al. (2013) in their theoretical paper, and by von Wallpach et al. (2017a) and Törmälä and Gyrd-Jones (2017) in their empirical works. From this perspective, research should focus on understanding which stakeholder performances co-create the corporate brand identity. The empirical works by von Wallpach et al. (2017a) and Törmälä and Gyrd-Jones (2017) attempt to understand this. Mäläskä et al. (2011) also have a very similar objective, even if they do not explicitly adhere to the performativity approach and instead focus on what they call stakeholder actions. The three are based on single case studies. However, by using multiple cases, it should be possible to understand which core categories of stakeholder performances co-create the corporate brand identity across organizations.

Overall, the first objective of this research is to explore how corporate brand identity is co-created by multiple internal and external stakeholders. The second objective is to understand which stakeholder performances co-create the corporate brand identity.

\section{Methodology and data analysis}

\subsection{Methodological approach}

In order to generate theory from emerging empirical data, this research uses qualitative case studies with inductive reasoning (e.g. Brown \& Eisenhardt, 1997; Corley \& 
Gioia, 2004). This approach is especially appropriate to study under-explored topics that still lack robust theory (Creswell \& Poth, 2017, p. 45). A case study is defined as "an empirical inquiry that investigates a contemporary phenomenon within its real-life context when the boundaries between phenomenon and context are not clearly evident and in which multiple sources of evidence are used" (Yin, 1989, p. 23). More precisely, this research adopts a multiple-case design since it allows for case comparisons and is "preferred in theorygenerating case studies" (Halinen \& Törnroos, 2005, p. 1291). Five cases are presented, providing more varied empirical evidence, and thus making the results more robust (Eisenhardt, 1991; Eisenhardt \& Graebner, 2007). The chosen number of cases - five - aligns with Eisenhardt's (1989) proposal of the appropriate number of cases to be included in multiple case study research (i.e., between four and ten). This provides certain generalizability but, at the same time, does not result in excessive complexity, which would inhibit the rich and thick descriptions of the social phenomena underpinning each case.

\subsection{Data collection and sample}

The five cases used in this research were purposefully selected to show different perspectives of the problem, and to increase the validity of the findings (Creswell \& Poth, 2017, p. 66). Although all five cases (A-E) are B2B corporate brands, they are of different size (from small to medium), from different sectors, and operate in different geographical contexts. B2B corporate brands were selected because they are grounded in social networks (Halinen \& Törnroos, 1998), where multiple stakeholders interact, form, and maintain ongoing and long-lasting relationships (Lindgreen \& Wynstra, 2005), during which they consciously or unconsciously co-create several brand aspects, including brand knowledge (von Wallpach \& Kreuzer, 2013), brand offerings (Ind et al., 2017), brand reputation (Koporcic \& Halinen, 2018), and brand identity (da Silveira et al., 2013). In addition, these 
stakeholder relationships are more intense, frequent, and cooperative in B2B contexts than in B2C settings (Markovic et al., 2018; Webster \& Keller, 2004), which makes B2B contexts more suitable to study corporate brand identity co-creation processes. Surprisingly, even if some research shows that $\mathrm{B} 2 \mathrm{~B}$ corporate brands can differentiate a company and strengthen its competitive advantage (Beverland et al., 2007), there is still limited research on B2B corporate brand-building processes in small and medium sized enterprises (SMEs) (Spence \& Essoussi, 2010). Therefore, we chose to exclude large multinational corporate brands and focus on SMEs. SMEs also provide better and easier access to the corporate brand founders, as well as those long-serving employees, who have been involved over time in the corporate brand identity co-creation process (Koporcic \& Halinen, 2018; Rode \& Vallaster, 2005). Finally, we narrowed our focus to established corporate brands operating in the market for at least two years. Thus, we did not sample start-ups with less than two years of experience, because we deemed that they might not possess sufficiently grounded and sustained core values (Törmälä \& Gyrd-Jones, 2017).

We collected primary data by conducting 37 semi-structured, narrative interviews among internal and external stakeholders spanning the five cases. Semi-structured, narrative interviews were chosen since the "narrative is a medium that is easy to construct, understand, convey and remember" (Makkonen et al., 2012, p. 291). Corporate brand A is an international business development organization within the life science sector. Corporate brand B is a Spanish consultancy in branding. Corporate brands C and D are international agencies specialized in organizing meetings, incentives, congresses, and events. Corporate brand $\mathrm{E}$ is a Spanish motor manufacturing specialist. The value of semi-structured, narrative interviews is that they allow interviewees to report freely the key events that they personally experienced in the past (Creswell \& Poth, 2017, p. 68), and they enable interviewees to express their personal understanding of reality (Polkinghorne, 2007). Narratives permit 
researchers to comprehend the dynamics of complex phenomena and unfolding processes over time. As Makkonen et al. (2012, p. 288) argue, "a narrative is similar to a process in that they both examine events in a particular context and follow a temporal structure." This is because narratives "portray events in a structured manner and offer a particular point of view of a situation through the use of plot" (Bartel \& Garud, 2009, p. 110). This is evident when our informants provide their interpretation of the meanings, goals, and events that led to the development of corporate brand identity. At the same time, narratives also "capture fragments of activity without a clear plot" (Bartel \& Garud, 2009, p. 110). In fact, our informants also reflect on the actions ascribed to them as stakeholders (by themselves and by others), and the actions performed by others (Hagberg \& Kjellberg, 2010). Thus, narratives were especially appropriate to illustrate stakeholders' own interpretations and reconstructions of the corporate brand identity co-creation process. The interview guide is provided in Appendix 1 and was used only to guide researchers with regard to the topics that were discussed. Questions were, however, open-ended, allowing respondents to tell the story in their own way.

The 37 semi-structured, narrative interviews lasted between 15 and 75 minutes. All interviews were recorded and transcribed. In order to adopt a balanced multi-stakeholder perspective on the corporate brand identity co-creation process, in each case we interviewed at least one of the founders, as well as top managers, employees, customers, and other external stakeholders. The respondents' diverse profiles within and across the five cases allowed us to develop understanding of the observed patterns, and build relationships among them to create a robust conceptual model (Goulding, 2005; Corbin \& Strauss, 2008, p. 88). Table 1 presents respondents' profiles and their distribution across the five cases. 


\subsection{Data analysis}

The data analysis was conducted using the Atlas.ti software. This software was found appropriate, given the large amount of narrative data that has been collected. All the cases were analyzed individually - i.e., case by case. A visual summary of the data analysis process is provided in Figure 1. The first stage of the analysis consisted of an open coding, aimed at identifying the key concepts and their properties (see example in Figure 2). Thereafter, in the axial coding stage, we focused on finding explanatory relationships between the concepts, by constantly comparing them and assembling them into higher-order concepts that formed the subcategories and final categories (see example in Figure 3) (Corbin \& Strauss, 2008, p. 105). Finally, in the selective coding stage, to build a novel theoretical framework, we compared the resulting categories and subcategories against the already existing literature (Goulding, 2005). Taking into consideration that this qualitative approach entails a constant comparative analysis between the already-analyzed and posteriorly-collected data, the processes of data collection and data analysis partially overlapped. This iterative approach allowed us to enhance the robustness of the findings (Eisenhardt, 1989; Goulding, 2005; Corbin \& Strauss, 2008, p.74).

\section{----- INSERT FIGURES 1, 2, AND 3 ABOUT HERE -----}

\subsection{Determining the quality of research}

The challenge in determining the quality of research when conducting qualitative case studies is that the research process itself is less transparent, in comparison with quantitative studies (Eriksson \& Kovalainen, 2008). To justify our methodological choices and potential biases, we followed Lincoln's and Guba's (1985) and Eriksson's and Kovalainen's (2008) studies on trustworthiness. 
First, to ensure credibility, we have collected enough data to support the findings and the generation of new knowledge. After conducting 37 face-to-face, semi-structured, narrative interviews, the saturation point was reached. In addition, we did not interfere or influence respondents' answers in any way.

Second, the credibility of data and its trustworthiness is enhanced further by using data triangulation (Bryman \& Bell, 2007). We have triangulated the interview data with data from archival materials, companies' webpages, marketing documents, presentations, statements of value proposition, customer feedback, and social media profiles, among others. These additional data were used to enrich the understanding of each case (e.g., tracing back how corporate brand identity was defined through drafts and marketing plans and comparing the corporate brand values listed on the webpage against those identified in the interviews).

Third, by comparing the new study to the already existing studies we achieved the potential for transferability (Eriksson \& Kovalainen, 2008). This was done in the theoretical part, when investigating similar studies on the topic. We did not aim to replicate their findings, but instead, to look at the similarities and to contribute further to the theoretical development of the corporate brand identity field.

Fourth, an external audit has been conducted by attending research seminars, where we presented our case studies to colleagues not involved in this research. This peer debriefing (Lincoln \& Guba, 1985), enables researchers to discuss different emerging patterns, propositions, data collection details, and analysis choices with peers. Feedback was crucial for improving the quality of our research and its trustworthiness.

Fifth, we confirmed the findings, by supporting the research with data, without the influence of the researchers' own interests. This was supplemented with triangulation of sources, where different informants from the same companies were interviewed. Analyst 
triangulation was also conducted, by co-authoring the study. This allowed interpretive analysis from different perspectives.

Finally, all the case study records, such as interview data and transcripts, coding schemes, contact records, and documents, have been saved, which allows the study to be concluded (Guba \& Lincoln, 1989).

\section{Findings}

The results of the data analysis show that corporate brand identity stems from the values of the founders, but is also a temporary outcome of a multi-stakeholder co-creation process.

\subsection{Corporate brand identity: The role of the founder(s)}

In all the cases, the interviews show that the corporate brand identity is a reflection of the founder's identity. When there are several founders, the corporate brand identity reflects their common shared values. This is illustrated in the quotes below.

"So, the company is a part of who I am and I am a part of the company... I must say more of my life is inside the company than outside. I feel, I am the company." (Corporate brand D; Founder A).

"This [corporate brand identity] is the DNA of the company, it's our DNA. This is something shared by both of us [B's founders]. And this is something that we try to communicate to our people" (Corporate brand B; Founder A).

Founders are committed to disseminating and nurturing the corporate brand identity because it is a reflection (or at least a very important part) of their personal identity. This connection between the founders' identity and the corporate brand identity is evident to employees, as shown in the previous quote, because they work side by side with the founders. 
Besides employees, other key stakeholders also recognize it, as illustrated in the following quotes.

"It's thanks to $\mathrm{X}$ and $\mathrm{Y}$ [B's founders]... I think these [corporate brand identity] values came from them because they are like that and they promoted them in the company $[. .$.$] Since they [B$ 's founders $]$ are like that, they succeeded in conveying it [corporate brand indentity] in a certain way..." (Corporate brand B; Employee A).

"I think the brand...transmits the idea that it's the company formed by its current founders, its current owners" (Corporate brand A; Manager B).

\subsection{Corporate brand identity: The outcome of the co-creation process}

However, once the founders expose the corporate brand identity to stakeholders, it is in constant flux. This is because various stakeholders continuously enact, reinterpret, and reperform it, giving rise to a multiplicity of corporate brand meanings. In fact, different stakeholders may hold competing or even conflicting interpretations of the corporate brand identity. For example, in the case of corporate brand B, while the founder assigns a positive meaning to the corporate brand identity, an employee has a more negative interpretation, as reflected in the quotes below. Here, corporate brand meaning is "agent-ascribed," and is closely related to the personal experiences and values of each stakeholder.

"We are problem-solvers, we like to say that we have this can-do attitude - that everything can be done - there's always, 'Yes, let's try' in our voice. We are flexible" (Corporate brand B; Founder A).

"We can do a lot of things, and that's a weakness, because we don't have a strong personality [identity]. The good point is that we never say, 'No, sorry, this is not in our portfolio, this is not the part of our job, so we are not going to do it.' No, we say, 
'We will do it for you.' This is why I think we are not $[\ldots]$ a strong brand. I think we don't have a lot of confidence in ourselves" (Corporate brand B; Employee B).

In essence, corporate brand identity is co-created by multiple internal and external stakeholders in an ongoing process, as illustrated by the below quote:

"I think it's a continuous process [...] Now I've been with the company for 4 years and $[\ldots]$ I think we had a lot of internal work to get clear what should be related to our brand [corporate brand identity] [...] We try to be aware of suggestions from stakeholders, from the industry stakeholders, from customers, but also from other stakeholders" (Corporate brand A; Manager A).

\subsection{Stakeholder performances co-creating the corporate brand identity}

According to the data analysis, the brand identity co-creation process occurs because of the engagement of diverse stakeholders in four different but interrelated performances: communicating; internalizing; contesting; and elucidating.

\subsubsection{Communicating}

Communicating has to do with transmitting the corporate brand identity to all the corporate brand's stakeholders. The data show how managers communicate the corporate brand identity to employees, customers and other relevant stakeholders by investing in different activities and media, such as posters in their offices, their website, and corporate videos.

"We promote the brand [...] trying to have actualized catalogs, trying to have an actualized website. And then another way is the focus on professional magazines. Our sector has two main magazines in Spain and Portugal, which are focused on our sector. So, we try to produce articles, to make advertising that transmits our 
knowledge and what can we offer to our customers." (Corporate brand E; Manager A).

Even if these activities are highly important, interviewees emphasize that founders and managers play an even more critical role in communicating the corporate brand identity, leading by example through their daily behavior.

"Since they [B's founders] are like that, they succeeded in conveying it [corporate brand identity] in a certain way [...] He [founder A] is dynamic. And it's contagious. They [founders] transmit what they are" (Corporate brand B; Employee A).

However, communicating the corporate brand identity is not only performed by founders and managers, but is done together with employees and even external stakeholders. When the corporate brand identity resonates with external stakeholders, they are likely to communicate and endorse the corporate brand identity among their contacts. The following quote reflects a customer's engagement in this practice.

"When we meet our competitors and friends in the trade there are often occasions when people would ask, okay, you know, I am planning to do something in Spain, can you recommend, can you suggest, you know, do you know of some company who can do this, this, this kind of work. And then of course, what comes to your mind, is your own experience with the company and when it comes to D, I have no hesitation recommending them as one of the reliable partners who... who believe in delivering quality service...I have no hesitation in recommending them. This is what I generally feel in my heart" (Corporate brand D; Customer A).

\subsubsection{Internalizing}


Internalizing is concerned with bringing the corporate brand identity to life, turning it into actual behaviors aligned with the corporate brand identity, and embedding it into the corporate brand's daily routines and actions. The following quotes illustrate this.

"Since we started, we tried to make people in the market understand that our product is reliable...but we also give 5 years warranty to mirror that, to explain that we are not just talking. We offer a long warranty, which means you can understand that we are reliable" (Corporate brand E; Manager A).

"Every time that we provide a service to our clients, we say we are efficient, simple, pragmatic in all that we do. The full service that we provide and the full project that we deliver, we present to our clients." (Corporate brand B; Founder A).

However, the data show that when employees have not received adequate training, it is more difficult for them to understand what the corporate brand identity is, and to internalize it, thus leading to a wider diversity of interpretations and behaviors.

"When I started working here, we didn't go to the training. It's not clear for me what the brand is or what the brand stands for. So, I take my decision and I sell to clients what I think the brand should be for my market, and that's it" (Corporate brand C; Employee B).

This is why the interviewees emphasize the relevance of training programs, especially for new recruits, to foster the internalization of the corporate brand identity, and to achieve a high degree of common enactment and interpretation of the corporate brand values. This is illustrated in the quote below.

"When someone new enters the company, we do training with this person. [...] And when we do training, we explain our methodology, and in a certain way our spirit, our philosophy" (Corporate brand B; Employee A). 
Here, it is interesting to note that interviewees emphasize that there is only the potential for consistent behavior when the personal values of the recruited employees align with the corporate brand identity. This can be seen in the quote below.

"I recruited them because they were very close to these values [...] But concerning the basic values, I think that people have to have them before coming into the company. Because you know, a person that is not ethical will never be ethical. So, it's a lost investment to try to educate this, right? So, there are some things that you can work on with people, and some that they have to have as a predisposition" (Corporate brand D; Founder).

Finally, even if training and recruitment play a relevant role, internalizing also heavily depends on an acculturation process that occurs as new hires immerse themselves in daily activities and forge relationships with their colleagues, customers, and other stakeholders. The quote below provides evidence of this.

"So, when someone, for example, gets into our team for the first time, we provide him or her with an inwards program. And we try to explain who we are, what we do, how do we do things, and we show them a lot of projects that we produced, ok? So that's part of the integration program. And then what makes them understand our proposal in terms of business and brand, is working with it on a daily basis" (Corporate brand B; Founder A).

\subsubsection{Contesting}

Contesting is concerned with stakeholders confronting the corporate brand identity with their perceptions of the corporate brand (i.e., corporate brand image). The quote below shows how a customer of corporate brand $\mathrm{C}$ compares the corporate brand's identity and image. 
"I think reliability is okay. They are reliable, okay. [...] Now, proximity I am not sure. This is what they would like, but [...] If the staff would have worked so closely with their clients, they wouldn't have negative feedback. So... I don't think they are achieving that. So this is probably what they want, but they... I don't think they are fulfilling this one. Then, the global coverage... It is and it is not, you know? It is a kind of... Good marketing tool, I think, but it is not really that their clients have given them any business for any other country than Spain. Global coverage is probably not their aspiration but it is a necessity. Specialization, they are specialized in what they do, this is true" (Corporate brand C; Customer B).

The following quote shows how contesting can also come from the stakeholders' evaluation of potential gaps between the corporate brand identity and the corporate brand image.

"[Discussing the corporate brand identity] Global because now it's very necessary because our competitors, a lot of them are global. [...] However, it's not exactly who we are ...because we have only three offices in Spain. [...] it's not seen internally." (Corporate brand C; Employee A).

Contesting also occurs when a stakeholder contrasts the corporate brand identity, not only with his/her perceptions of the corporate brand, but also with the corporate brand image that competitors hold, as illustrated by the following quote.

"And if you compare their [corporate brand A] website with one of their competitors, approach is a little bit softer, which is going to appeal to a certain type of client, probably a smaller business. They have a look and appeal that is more approachable. And so, I think that it harks back to the values" (Corporate brand A; Customer B). Contesting also takes place when a stakeholder compares and contrasts his/her perceptions of the corporate brand with someone else's, as shown by the quote below. 
"D has been widely appreciated in their work not only by us, but by also some of our competitors in India. [...] So, when we meet them, there is obviously an exchange of views and ideas where people are able to sort of share and tell us the good and the bad things about different places [...] we talk, and we take each other's opinions, sometimes advice and sometimes also get ideas." (Corporate brand D; Customer A). Contesting can result in either stakeholders reaffirming the corporate brand identity as defined by managers, or challenging it. The latter happens when there is a clear gap between the corporate brand identity and the corporate brand image. When this gap exists and the contesting stakeholders interact with the managers, a tension can arise, as evidenced by the quote below.

"The identity that the company was trying to express earlier was the modern look that the CEO thought the market would appreciate more. However, I told him, you are conservative, you are old-fashioned...but also trustworthy. But he said: this is not sexy to the market... or he told me something like that. Yeah, but that's who you are, I said. And there's people who will appreciate if you are like that." (Corporate brand C; Employee B).

Thus, contesting is not going to be effective unless there is interaction between the stakeholders contesting the corporate brand identity and the company's boundary spanners, such as salespeople, managers, or even the CEO. This is well illustrated in the quote below, where corporate brand's B founder and current CEO explains how he became aware of customers' perceptions and how this influenced internal strategic decisions.

"In terms of philosophy, of way of interacting between agencies and clients. I think this is something very perverted, and when talking to clients, they complain very much about this: 'They have an attitude, they are too expensive, they abuse us when they can after sending the contract...' All these kind of things. [...] and we wanted 
really to create something different in a philosophical point of view". (Corporate brand B; Founder).

In essence, when contesting stakeholders interact with managers, a certain tension can arise and can have an impact on the corporate brand identity co-creation process. As illustrated by the following quote, managers understand the importance of this process, and try to create mechanisms that facilitate contesting stakeholders transmitting their feedback to the organization.

"We see the importance of this, of stakeholders giving their opinion about our value proposition. [...] And we have internal processes to get this. To get this right. Whenever we have a suggestion, we know how to process it. [...] And I think there is the constant inflow of suggestions and this of course has an impact on the value proposition, it's clear. That's filling in the values with real work." (Corporate brand A; Manager A).

All in all, contesting occurs when stakeholders contrast the corporate brand identity with the perceptions of the corporate brand (i.e., corporate brand image). This is a comparative process, in which stakeholders can also take into consideration competitors. Contesting can also happen when stakeholders are exposed to the assessments of others. However, for contesting to be effective, contesting stakeholders need to interact with the company's boundary spanners, such as salespeople, managers, or even the CEO.

\subsubsection{Elucidating}

Elucidating is a conversational process by which managers, together with stakeholders, discuss and reconcile the diverse corporate brand identity enactments and interpretations, aiming to build a shared understanding of the corporate brand identity. Customers and employees play a key role in this process, as illustrated in the quotes below. 
[Speaking about the corporate brand identity] "I started to look at the values that D had. And these values are basically derived from the employees of D. [...] I had a set of interviews with the employees to get to know what were their perceptions on the D brand. And not only the current perceptions, but what they want D brand to become and to be perceived as. [...] That's why I have decided to focus specifically on these values; on sincerity, transparency, and authenticity as a response to the current market situation" (Corporate brand D; Manager A).

"It is a process open for suggestions. [...] And this is of course in part done because we are asking our customers what has been done to your satisfaction, what could have been done better. And I think there is the constant inflow of suggestions and this of course has an impact on the value proposition, it's clear. That's filling in the values with real work. I think this is a constant process" (Corporate brand A; Manager A).

Through this conversational process, the different stakeholders express their understanding of how the corporate brand identity should change and develop further. This is also evident in the following quote.

"I think it was a network process, working and seeing what was around us. I mean, we were sure that we didn't want to be like others, because our main customers explained things about these others and they were not happy, not comfortable about their attitudes. So, for clients it was a value that we were different. This is why we made a big effort in developing along this line... The actual values are from us. [...] But they were stronger because this is one of the characteristics that customers like" (Corporate brand A; Founder A).

As founder A explains, managers opt for emphasizing and developing some of the corporate brand meanings because of customer expectations. This underscores the pressure stakeholders put on managers to adapt the corporate brand identity. In essence, there is an 
inherent tension between managers (who are more conservative and protective of the corporate brand identity) and other stakeholders (who instead promote alternative corporate brand meanings). Elucidating reconciles these different perspectives, and pushes managers to build a deeper understanding of the corporate brand identity. According to our interviews, this process clarifies and enriches the corporate brand identity, but very rarely disrupts it, because managers and especially founders are very protective of the corporate brand's core values. This implies that the corporate brand identity co-creation process is dynamic, but also enduring, as illustrated in the quotes below.

"We have not changed the [corporate brand identity core/foundational] values but $[\ldots]$ we better understand the idea $[\ldots]$ we have really used the right words and we have more clear ideas on the company than 10 years ago" (Corporate brand A; Founder A).

"I think that these are three really core values of B [corporate brand identity]. It's really what $\mathrm{B}$ is. I mean it changes, it has evolved during these eight years but this spirit is still here" (Corporate brand B; Founder B).

\section{Discussion and conclusion}

\subsection{Theoretical contributions}

This research contributes to the brand management literature by shedding light on how the corporate brand identity co-creation process takes place. Our findings show that four stakeholder performances co-create the corporate brand identity: communicating; internalizing; contesting; and elucidating. Our findings align with previous research, both in B2C (e.g., Black \& Veloutsou, 2017; Kornum et al., 2017; von Wallpach et al., 2017a) and B2B contexts (e.g., Mäläskä et al., 2011; Törmälä \& Gyrd-Jones, 2017, Koporcic \& Halinen, 2018), which underscores how corporate brand identity is co-created. However, to the best of 
our knowledge, our study is among the first to empirically explore the corporate brand identity co-creation process in B2B contexts with multiple internal and external stakeholders. In our study, we consider the views of founders, managers, employees, customers, and other external stakeholders in building a balanced perspective of the corporate brand identity cocreation process and an understanding of the performances these stakeholders engage in.

Our findings support the argument that a corporate brand identity reflects the founders' core values and steers strategic decisions (Törmälä \& Gyrd-Jones, 2017). Additionally, they show how corporate brand identity is co-created through a social process that unfolds over time due to interactions between multiple internal and external stakeholders (Iglesias et al., 2013; Vallaster \& von Wallpach, 2013; Koporcic \& Halinen, 2018). Our findings show there is an ongoing tension between managers (who pursue the role of brand custodians and want to preserve the corporate brand identity and its foundational core values) and stakeholders (who by reinterpreting and enacting the corporate brand identity give rise to a polysemous bundle of meanings; Michel, 2017). Accordingly, it is incumbent on managers to adapt the corporate brand identity, in tune with the influence of stakeholders in an ongoing adaptive co-creative process. This highlights that identity is unstable (Gioia, Schultz, \& Corley, 2000, p. 64) and that a strong monolithic corporate brand identity is only a "temporary stabilization in an ongoing change process" (Törmälä \& Gyrd-Jones, 2017, p. 83). However, our findings also show that managerial resistance to disruptive changes to the corporate brand identity mitigate against radical change and lead to more progressive and subtle changes in the corporate brand identity. Overall, our findings show that corporate brand identity is a temporary outcome of a co-creation process that entails four stakeholder performances (i.e., communicating, internalizing, contesting, and elucidating). As the cocreation process is ongoing in nature, the corporate brand identity changes over time. These key findings are portrayed in Figure 4. 
----- INSERT FIGURE 4 ABOUT HERE -----

Based on the above discussion and the need to better understand the corporate brand identity co-creation process (von Wallpach et al., 2017a) from a more relational and multistakeholder perspective (e.g., Mäläskä et al., 2011; da Silveira et al., 2013), we put forward the following proposition:

P1. Corporate brand identity co-creation is a dynamic and ongoing process coperformed by multiple internal and external stakeholders that entails four different but interrelated performances: communicating; internalizing; contesting; and elucidating.

The above proposition reinforces the need to further explore and comprehend those stakeholder performances that co-create corporate brand identity (Hemetsberger \& Mühlbacher, 2009). This performative identity co-creation perspective aligns with the recent theoretical work by da Silveira et al. (2013), and the empirical works by von Wallpach et al. (2017a) and Törmälä and Gyrd-Jones (2017). Our research empirically builds on these works, but by using multiple cases and a balanced multi-stakeholder perspective (i.e., various internal and external stakeholders), it allows for a greater generalizability of the findings, which is essential for theory building (Eisenhardt, 1991). More specifically, our study identifies and describes four categories of stakeholder performances that co-create corporate brand identity, and argues for the following propositions:

P1a. Communicating involves all the activities performed by stakeholders to transmit the corporate brand identity.

P1b. Internalizing involves all the activities performed by stakeholders to bring the corporate brand identity to life, turn it into actual behaviors, and embed it into the corporate brand's daily routines and actions. 
P1c. Contesting involves all the activities performed by stakeholders to confront the corporate brand identity with the perceptions of the corporate brand (i.e., corporate brand image). This is a comparative process, where stakeholders can take into consideration the competition and the assessments of other stakeholders.

P1d. Elucidating involves all the activities performed by stakeholders to reconcile the tensions caused by the diverse corporate brand identity enactments and interpretations, and to foster an evolved shared understanding of the corporate brand identity.

Table 2 summarizes the key contributions of the current research in comparison with the previous studies in the domain.

\section{----- INSERT TABLE 2 ABOUT HERE -----}

\subsection{Managerial implications}

This research has relevant implications for managers. First, managers should understand that they do not have absolute control over their brands and what they mean to stakeholders. Instead, they must be aware that corporate brand identity is organic, co-created by multiple stakeholders, and in constant flux (Batey, 2015; Iglesias et al., 2013). This demands a new form of brand governance (Hatch \& Schultz, 2010), and suggests that managers should no longer see themselves as "brand guardians" who rigidly try to keep and preserve the purity of the corporate brand identity. Instead, they should act as "conductors" (Michel, 2017) who allow the corporate brand identity to progressively change by reconciling multiple stakeholder perspectives, while still attempting to preserve its core values. This requires a new participatory leadership style that is more open, humble, and capable of 
embracing the inputs of multiple stakeholders (Ind et al., 2013; Ind et al., 2017). This is especially relevant for SMEs which, compared to large multinational companies, tend to develop closer relationships with their stakeholders. Thus, by adopting the suggested leadership style, SMEs may be able to better integrate their stakeholders' insights into the corporate brand identity co-creation process.

Second, if managers are to embrace multi-stakeholder participation in corporate brand identity co-creation, they need to understand the performances stakeholders engage in when co-creating the corporate brand identity (i.e., communicating, internalizing, contesting, and elucidating). The implication of this is that managers need to pay attention to using effective communication channels to share the corporate brand identity and to align their actions with it. Internally, managers can play an important facilitation role in helping the internalization of the co-created identity by fostering internal branding policies and practices oriented toward recruitment and training. Externally, managers can engage customers and other stakeholders in conversations that help to elucidate the corporate brand identity, for instance, via online brand communities. This role is especially important in B2B contexts, as B2B corporate brands are based on complex business networks with professional partners, who have strong and long-standing interests in jointly enhancing their related assets (Andersen, 2005).

\subsection{Limitations and future research}

Notwithstanding its theoretical contributions and managerial implications, this research has several limitations. First, although interviews are the main source of data in qualitative methods (Eisenhardt, 1989), they entail an issue of double hermeneutics. This means that the interviewees first interpret reality within their social contexts, and then the researchers conduct a subsequent interpretation of the interviewees' responses. Although we have triangulated the data with secondary sources, future research could further triangulate 
them with other data sources, such as a netnography of internal and external brand communities where different stakeholders discuss and negotiate corporate brand meanings.

Second, although this research includes five case studies of corporate brands that have different sizes (from small to medium), are from different sectors, and operate in different geographies, the external validity of the findings is still a concern. Thus, future research should extend the number of cases. An in-depth cross-cultural analysis would be relevant in this regard, as it could uncover the different dynamics in corporate brand identity co-creation across countries and cultures.

Third, this research only includes B2B corporate brands, and therefore its findings are only representative of $\mathrm{B} 2 \mathrm{~B}$ contexts. Thus, future research could complement our findings by conducting case studies in B2C settings, and analyze the similarities and differences on identity co-creation between B2B and B2C corporate brands.

Apart from dealing with the aforementioned limitations, future research could also focus on understanding the leadership style that managers should promote if they want to move from being brand custodians to brand conductors. In a similar vein, it would also be valuable to determine the type of corporate culture that best supports a more open and participatory corporate brand identity co-creation process. Finally, regarding the dynamics of the corporate brand identity co-creation process, it can be expected that the four categories of performances identified in this paper will serve as a starting point for a more developed conceptualization of the phenomenon. The propositions of this study should be further examined to create a deeper understanding of the relational and multi-stakeholder perspective of corporate brand identity co-creation, which is enacted by multiple internal and external stakeholders.

\section{References}


Aaker, D. A. (1996). Building strong brands. Simon \& Schuster, UK Ltd: The Free Press.

Abimbola, T., \& Kocak, A. (2007). Brand, organization identity and reputation: SMEs as expressive organizations: A resources-based perspective. Qualitative Market Research: An International Journal, 10(4), 416-430.

Albert, S., \& Whetten, D. A. (1985). Organizational identity: Research in organizational behavior. Greenwich, CT.

Andersen, P. H. (2005). Relationship marketing and brand involvement of professionals through web-enhanced brand communities: The case of Coloplast. Industrial Marketing Management, 34(3), 285-297.

Anselmsson, J., Vestman Bondesson, N., \& Johansson, U. (2014). Brand image and customers' willingness to pay a price premium for food brands. Journal of Product \& Brand Management, 23(2), 90-102.

Austin, J. L. (1975). How to do things with words. Oxford university press.

Balmer, J. M. T. (1995). Corporate branding and connoisseurship. Journal of General Management, 21(1), 24-46.

Balmer, J. M. T., \& Grey, E. R. (2003). Commentary - corporate brands: What are they? What of them? European Journal of Marketing, 37(7/8), 972-997.

Bartel, C. A., \& Garud, R. (2009). The role of narratives in sustaining organizational innovation. Organization Science, 20(1), 107-117.

Batey, M. (2015). Brand Meaning: Meaning, myth and mystique in today's brands. Routledge.

Bendixen, M., Bukasa, K. A., \& Abratt, R. (2004). Brand equity in the business-to-business market. Industrial Marketing Management, 33(5), 371-380.

Bengtsson, A., \& Servais, P. (2005). Co-branding on industrial markets. Industrial Marketing Management, 34(7), 706-713. 
Beverland, M., Napoli, J., \& Lindgreen, A. (2007). Industrial global brand leadership: A capabilities view. Industrial Marketing Management, 36(8), 1082-1093.

Biraghi, S., \& Gambetti, R. C. (2015). Corporate branding: Where are we? A systematic communication-based inquiry. Journal of Marketing Communications, 21(4), 260283.

Black, I., \& Veloutsou, C. (2017). Working consumers: Co-creation of brand identity, consumer identity and brand community identity. Journal of Business Research, 70, 416-429.

Brown, S. L., \& Eisenhardt, K. M. (1997). The art of continuous change: Linking complexity theory and time-paced evolution in relentlessly shifting organizations. Administrative Science Quarterly, 1-34.

Bryman, A., \& Bell, E. (2007). Business research strategies. Business research methods.

Butler, L. (2010). Performative agency. Journal of Cultural Economy, 3(2), 147-161.

Chang, Y., Wang, X., \& Arnett, D. B. (2018). Enhancing firm performance: The role of brand orientation in business-to-business marketing. Industrial Marketing Management, 72, 17-25.

Cho, E., \& Fiore, A. M. (2015). Conceptualization of a holistic brand image measure for fashion-related brands. Journal of Consumer Marketing, 32(4), 255-265.

Corbin, J., \& Strauss, A. (2008). Basics of Qualitative Research: Techniques and Procedures for Developing Grounded Theory (3rd ed.). Thousand Oaks, CA: Sage

Corley, K. G., \& Gioia, D. A. (2004). Identity ambiguity and change in the wake of a corporate spin-off. Administrative Science Quarterly, 49(2), 173-208.

Creswell, J. W., \& Poth, C. N. (2017). Qualitative inquiry and research design: Choosing among five approaches (4th edition). Sage Publications. 
Csaba, F. F., \& Bengtsson, A. (2006). Rethinking identity in brand management. Brand Culture, 118-135.

da Silveira, C., Lages, C., \& Simões, C. (2013). Reconceptualizing brand identity in a dynamic environment. Journal of Business Research, 66(1), 28-36.

de Chernatony, L. (1996). 2001 - The brand management odyssey. Journal of General Management, 21(4), 15-30.

de Chernatony, L. (1999). Brand management through narrowing the gap between brand identity and brand reputation. Journal of Marketing Management, 15(1-3), 157-179.

de Roeck, K., Maon, F., \& Lejeune, C. (2013). Taking up the challenge of corporate branding: An integrative framework. European Management Review, 10(3), 137-151.

Eisenhardt, K. M. (1989). Building theories from case study research. Academy of Management Review, 14(4), 532-550.

Eisenhardt, K. M. (1991). Better stories and better constructs: The case for rigor and comparative logic. Academy of Management Review, 16(3), 620-627.

Eisenhardt, K. M., \& Graebner, M. E. (2007). Theory building from cases: Opportunities and challenges. Academy of Management Journal, 50(1), 25-32.

Eriksson, P., \& Kovalainen, A. (2015). Qualitative methods in business research: A practical guide to social research. Sage.

Essamri, A., McKechnie, S., \& Winklhofer, H. (2019). Co-creating corporate brand identity with online brand communities: A managerial perspective. Journal of Business Research, 96, 366-375.

Gioia, D. A. (1998). From individual to organizational identity. Identity in Organizations: Building Theory Through Conversations, 11, 17-31.

Gioia, D. A., Schultz, M., \& Corley, K. G. (2000). Organizational identity, image, and adaptive instability. Academy of Management Review, 25(1), 63-81. 
Goffman, E. (1959). The Presentation of Self. Butler, Bodies that Matter.

Goffman, E. (1967). On face-work. Interaction ritual, 5-45.

Goulding, C. (2005). Grounded theory, ethnography and phenomenology. European Journal of Marketing, 39(3/4), 294-308.

Guba, E. G., \& Lincoln, Y. S. (1989). Fourth generation evaluation. Sage.

Hagberg, J., \& Kjellberg, H. (2010). Who performs marketing? Dimensions of agential variation in market practice. Industrial Marketing Management, 39(6), 1028-1037.

Halinen, A., \& Törnroos, J.Å. (1998). The role of embeddedness in the evolution of business networks. Scandinavian Journal of Management, 14(3), 187-205.

Hatch, M. J. \& Schultz, M. (2010). Toward a theory of brand co-creation with implications for brand governance. Brand Management, 17(8), 590-604.

Hatch, M. J., \& Schultz, M. (2002). The dynamics of organizational identity. Human relations, 55(8), 989-1018.

Hemetsberger, A., \& Mühlbacher, H. (2009, May). Do Brands Have an Identity? A Critical Reflection and Extension of the Brand Identity Construct. In 38th EMAC Conference, Nantes.

Iglesias, O., \& Bonet, E. (2012). Persuasive brand management: How managers can influence brand meaning when they are losing control over it. Journal of Organizational Change Management, 25(2), 251-264.

Iglesias, O., Ind, N., \& Alfaro, M. (2013). The organic view of the brand: A brand value cocreation model. Journal of Brand Management, 20(8), 670-688.

Iglesias, O., Markovic, S., Singh, J. J., \& Sierra, V. (2019). Do customer perceptions of corporate services brand ethicality improve brand equity? Considering the roles of brand heritage, brand image, and recognition benefits. Journal of Business Ethics, 154(2), 441-459. 
Ind, N. (2009). The organic organization: Freedom, creativity and the search for fulfilment. New York: Atropos press.

Ind, N. Iglesias, O., \& Schultz, M. (2013). Building brands together: Emergence and outcomes of co-creation. California Management Review, 55(3), 5-26.

Ind, N., Iglesias, O., \& Markovic, S. (2017). The co-creation continuum: From tactical market research tool to strategic collaborative innovation method. Journal of Brand Management, 24(4), 310-321.

Kapferer, J. N. (2008). The new strategic brand management: Creating and sustaining brand equity long term. London: Kogan Page.

Kapferer, J.N. (2012). The new strategic brand management: Advanced insights and strategic thinking. London: Kogan Page.

Keller, K. L. (1993). Conceptualizing, measuring, and managing customer-based brand equity. Journal of Marketing, 57(1), 1-22.

Koporcic, N., \& Halinen, A. (2018). Interactive Network Branding: Creating corporate identity and reputation through interpersonal interaction. IMP Journal, 12(2), 392408.

Kornum, N., Gyrd-Jones, R., Al Zagir, N., \& Brandis, K. A. (2017). Interplay between intended brand identity and identities in a Nike related brand community: Co-existing synergies and tensions in a nested system. Journal of Business Research, 70, 432-440.

Lincoln, Y. S., \& Guba, E. G. (1985). Establishing trustworthiness. Naturalistic Inquiry, 289, 331.

Lindgreen, A., \& Wynstra, F. (2005). Value in business markets: What do we know? Where are we going? Industrial Marketing Management, 34(7), 732-748. 
Low, J., \& Blois, K. (2002). The evolution of generic brands in industrial markets: The challenges to owners of brand equity. Industrial Marketing Management, 31(5), 385392.

Lucarelli, A., \& Hallin, A. (2015). Brand transformation: A performative approach to brand regeneration. Journal of Marketing Management, 31(1-2), 84-106.

Makkonen, H., Aarikka-Stenroos, L., \& Olkkonen, R. (2012). Narrative approach in business network process research-Implications for theory and methodology. Industrial Marketing Management, 41(2), 287-299.

Mäläskä, M., Saraniemi, S., \& Tähtinen, J. (2011). Network actors' participation in B2B SME branding. Industrial Marketing Management, 40(7), 1144-1152.

Markovic, S., Iglesias, O., Singh, J. J., \& Sierra, V. (2018). How does the perceived ethicality of corporate services brands influence loyalty and positive word-of-mouth? Analyzing the roles of empathy, affective commitment, and perceived quality. Journal of Business Ethics, 148(4), 721-740.

Merrilees, B. (2007). A theory of brand-led SME new venture development. Qualitative Market Research: An International Journal, 10(4), 403-415.

Merz, M. A., He, Y., \& Vargo, S.L. (2009). The evolving brand logic: A service-dominant logic perspective. Journal of the Academy of Marketing Science, 37(3), 328-344.

Michel, G. (2017). From brand identity to polysemous brands: Commentary on "Performing identities: Processes of brand and stakeholder identity co-construction". Journal of Business Research, 70, 453-455.

Michell, P., King, J., \& Reast, J. (2001). Brand values related to industrial products. Industrial Marketing Management, 30(5), 415-425.

Morsing, M., \& Kristensen, J. (2002). The question of coherency in corporate branding - over time and across stakeholders. Journal of Communication Management, 6(1), 24-40. 
Mudambi, S. (2002). Branding importance in business-to-business markets: Three buyer clusters. Industrial marketing management, 31(6), 525-533.

Muniz, A. M., \& O’Guinn, T. C. (2001). Brand community. Journal of Consumer Research, $27(4), 412-432$.

Ohnemus, L. (2009). B2B branding: A financial burden for shareholders? Business Horizons, $52(2), 159-166$.

Polkinghorne, D. E. (2007). Validity issues in narrative research. Qualitative Inquiry, 13(4), 471-486.

Rode, V., \& Vallaster, C. (2005). Corporate branding for start-ups: The crucial role of entrepreneurs. Corporate Reputation Review, 8(2), 121-135.

Roper, S., \& Davies, G. (2007). The corporate brand: Dealing with multiple stakeholders. Journal of Marketing Management, 23(1-2), 75-90.

Schultz, M., Antorini, Y. and Csaba, F. (Eds) (2005), Towards the Second Wave of Corporate Branding: Corporate Branding Purpose/People/Process, Copenhagen: Copenhagen Business School.

Spence, M., \& Essoussi, H. L. (2010). SME brand building and management: An exploratory study. European Journal of Marketing, 44(7/8), 1037-1054.

Törmälä, M., \& Gyrd-Jones, R. I. (2017). Development of new B2B venture corporate brand identity: A narrative performance approach. Industrial Marketing Management, 65, $76-85$.

Urde, M. (2003). Core value-based corporate brand building. European Journal of Marketing, 37(7/8), 1017-1040.

Vallaster, C., \& von Wallpach, S. (2013). An online discursive inquiry into the social dynamics of multi-stakeholder brand meaning co-creation. Journal of Business Research, 66(9), 1505-1515. 
Van de Ven, A. H. (1992). Suggestions for studying strategy process: A research note. Strategic Management Journal, 13(S1), 169-188.

von Wallpach, S., \& Kreuzer, M. (2013). Multi-sensory sculpting (MSS): Eliciting embodied brand knowledge via multi-sensory metaphors. Journal of Business Research, 66(9), $1325-1331$.

von Wallpach, S., Hemetsberger, A., \& Espersen, P. (2017a). Performing identities: Processes of brand and stakeholder identity co-construction. Journal of Business Research, 70, 443-452.

von Wallpach, S., Voyer, B., Kastanakis, M., \& Mühlbacher, H. (2017b). Co-creating stakeholder and brand identities: Introduction to the special section. Journal of Business Research, 70, 395-398.

Webster, F. E., \& Keller, K. L. (2004). A roadmap for branding in industrial markets. Journal of Brand Management, 11(5), 388-402.

Wong, Y. H., \& Merrilees, B. (2005). A brand orientation typology for SMEs: A case research approach. Journal of Product \& Brand Management, 14(3), 155-162.

Yin, R. K. (1989). Case Study Research (revised edition). Beverly Hills: Sage. 
TABLES AND FIGURES

Table 1. Theoretical sample (number of interviews).

\begin{tabular}{lcccccc}
\hline & A & B & C & D & E & Total \\
\hline Founder(s) & 2 & 2 & 1 & 1 & - & 6 \\
Managers & 2 & - & 2 & 2 & 1 & 7 \\
Employees & 1 & 2 & 3 & 1 & 1 & 8 \\
Customers & 2 & 1 & 2 & 2 & 1 & 8 \\
Suppliers & - & - & 4 & 2 & 1 & 7 \\
Other (external) stakeholders & - & - & 1 & - & - & 1 \\
\hline Total & 7 & 5 & 13 & 8 & 4 & 37 \\
\hline
\end{tabular}

Figure 1. Data analysis process.
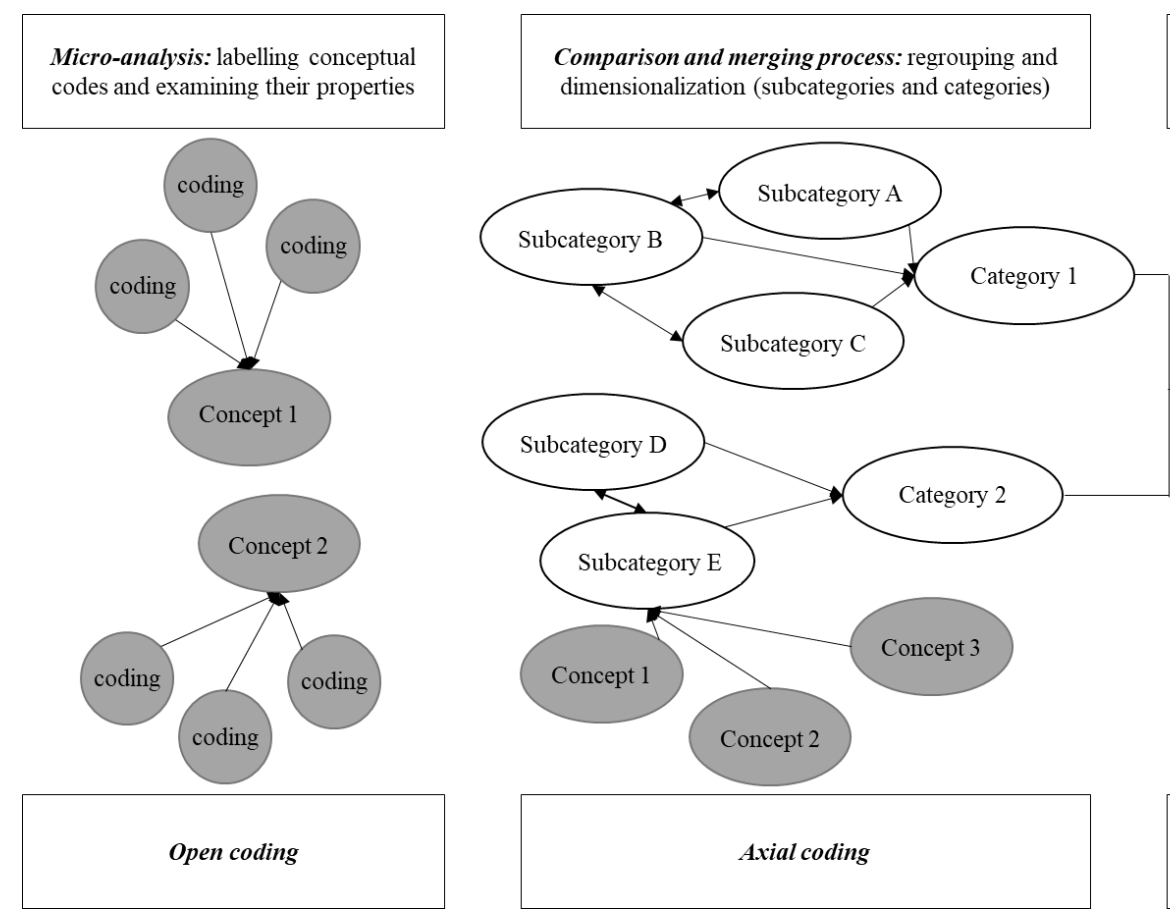
Integrating and theorizing: emerging theory
and literature comparison

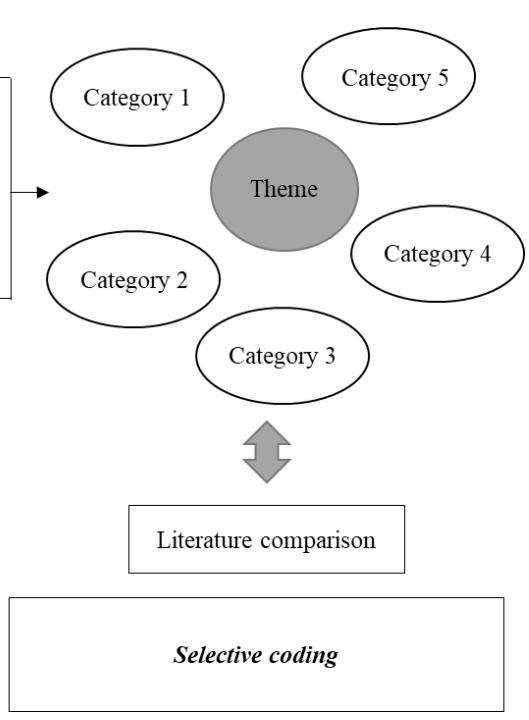


Figure 2. Illustration of open coding.

Back then, 6 years ago [during the internship], the $\mathrm{CEO}$ was talking about innovating. $(\underline{C E O \text { speech }}) \mathrm{I}$ think their slogan was " 25 years... Or, 35 years innovating." (communication slogan) What innovation are you talking about (laughs)? You are not an R\&D focused company. (contesting CEO $\underline{\text { speech }})<\ldots>$ Don't tell things that are not true (contesting CEO speech), you are not creating anything new! (contesting CEO speech) They had a logo that reminds me of Accenture more than anything else (comparing brand materials with competitors), and I'm like... Are you IT? (laughs) IT consulting, advising company $-\mathrm{I}$ don't know. (contesting CEO speech) $\ldots<\ldots>$ it is not who he is, or what the company is. (contesting CEO speech) $<\ldots>$ Let's ask them how much percentage goes to $\mathrm{R} \& \mathrm{D}$, let's ask that. Zero! (comparing brandidentity with own experience) And you are talking about innovation. You know, this is... Contradictory, totally contradictory (contesting CEO speech). The brand is trying to express something that is not there. (comparing brand identity withown experience)

Note: Conceptual names are italicized and underscored. In vivo codes are italicized.

Figure 3. Illustration of emerging category from axial coding.

Concepts
Subcategories

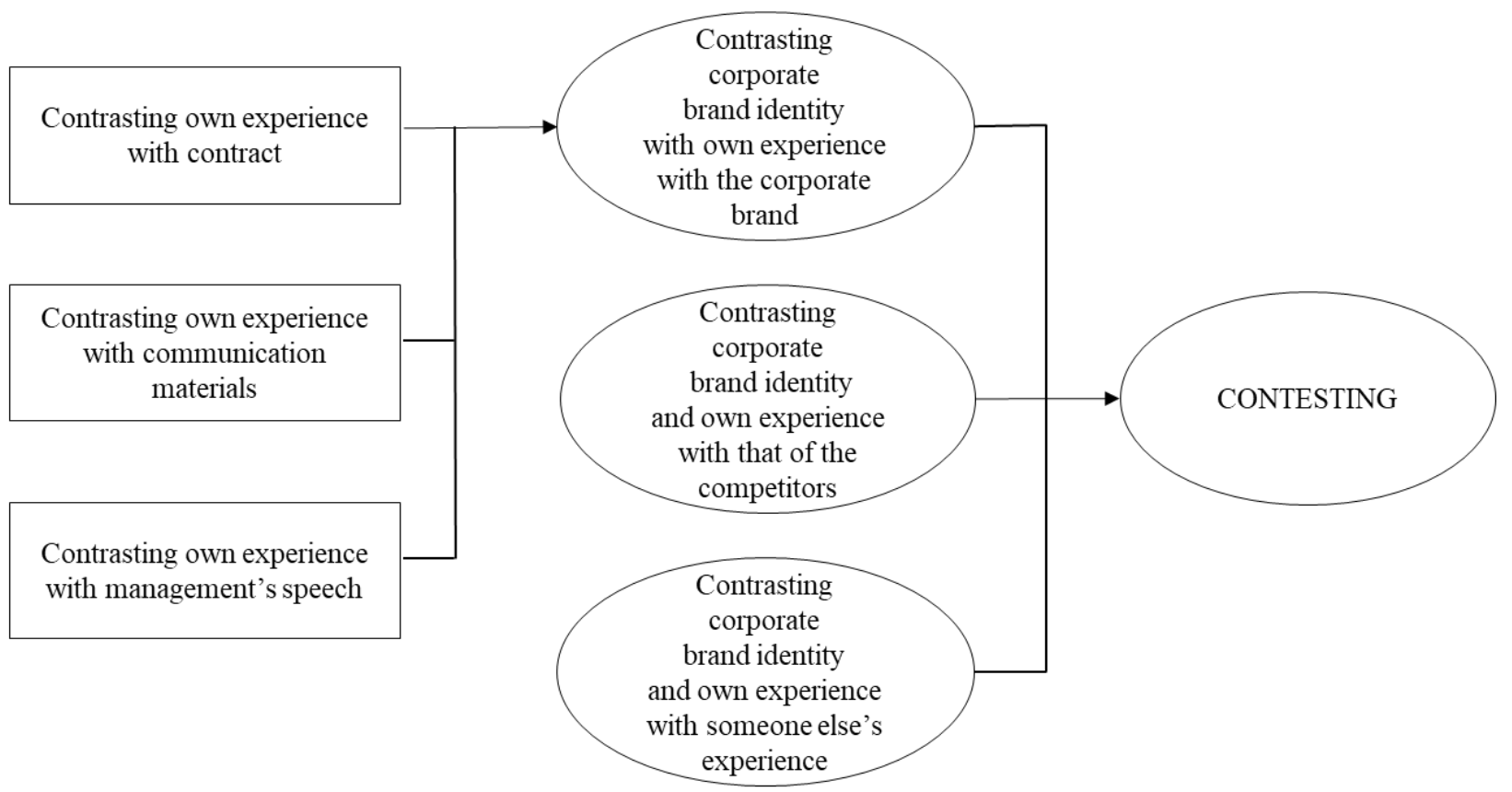

Contrasting own experience with contract

Contrasting own experience with communication materials

Contrasting own experience with management's speech
Category 
Table 2. Summary of key contributions vs previous research.

\begin{tabular}{|c|c|c|c|c|c|c|}
\hline \multirow[t]{2}{*}{ PAPER } & \multicolumn{2}{|c|}{ CONTEXT } & \multicolumn{2}{|c|}{ STAKEHOLDERS RESEARCHED } & \multicolumn{2}{|c|}{ CONTRIBUTION } \\
\hline & $\mathrm{B} 2 \mathrm{C}$ & B2B & Internal & External & $\begin{array}{l}\text { Description of corporate } \\
\text { brand identity as a dynamic } \\
\text { co-created process }\end{array}$ & $\begin{array}{l}\text { Description of corporate } \\
\text { brand identity co-creation } \\
\text { performances }\end{array}$ \\
\hline $\begin{array}{l}\text { Black and Velotsou } \\
\text { (2017) }\end{array}$ & Yes & No & $\begin{array}{l}\text { Yes } \\
\text { Excluding } \\
\text { founders }\end{array}$ & Yes & Yes & No \\
\hline $\begin{array}{l}\text { Da Silveira et al. } \\
(2013)\end{array}$ & Yes & No & Theoretical & & $\begin{array}{l}\text { Yes } \\
\text { Provide first theoretical } \\
\text { propositions }\end{array}$ & No \\
\hline \begin{tabular}{|l} 
Koporcic and \\
Halinen (2018)
\end{tabular} & No & Yes & Yes & Yes & $\begin{array}{l}\text { Yes } \\
\text { They focus on co-creation of } \\
\text { both the identity and } \\
\text { reputation, as two elements of } \\
\text { a corporate brand. }\end{array}$ & No \\
\hline $\begin{array}{l}\text { Kornum et al. } \\
(2017)\end{array}$ & Yes & No & No & Yes & Yes & No \\
\hline $\begin{array}{l}\text { Mäläskä et al. } \\
\text { (2011) }\end{array}$ & No & Yes & Yes & No & $\begin{array}{l}\text { Yes } \\
\text { Although they do not } \\
\text { explicitly refer to brand } \\
\text { identity, but branding }\end{array}$ & $\begin{array}{l}\text { No } \\
\text { Although they talk about } \\
\text { actions instead of } \\
\text { performances. Results rely on } \\
\text { one interview per case. }\end{array}$ \\
\hline $\begin{array}{l}\text { Törmälä and Gyrd- } \\
\text { Jones (2017) }\end{array}$ & No & Yes & Yes & No & Yes & $\begin{array}{l}\text { No } \\
\text { Although they describe key } \\
\text { activities related to turning } \\
\text { points }\end{array}$ \\
\hline $\begin{array}{l}\text { von Wallpach et al. } \\
(2017 b)\end{array}$ & Yes & No & $\begin{array}{l}\text { Yes } \\
\text { Excluding } \\
\text { founders } \\
\end{array}$ & Yes & Yes & \begin{tabular}{|l} 
Yes \\
Single case-related \\
performances (LEGO)
\end{tabular} \\
\hline $\begin{array}{l}\text { CURRENT } \\
\text { STUDY }\end{array}$ & No & Yes & $\begin{array}{l}\text { Yes } \\
\text { Including } \\
\text { founders }\end{array}$ & Yes & $\begin{array}{l}\text { Yes } \\
\text { Reconceptualization of the } \\
\text { corporate brand identity } \\
\text { construct from a relational } \\
\text { and multi-stakeholder } \\
\text { perspective }\end{array}$ & $\begin{array}{l}\text { Yes } \\
\text { Identification and description } \\
\text { of the core categories of } \\
\text { performances by multiple } \\
\text { internal and external } \\
\text { stakeholders that drive } \\
\text { corporate brand identity } \\
\text { co-creation in B2B contexts }\end{array}$ \\
\hline
\end{tabular}

Figure 4. Corporate brand identity co-creation process.

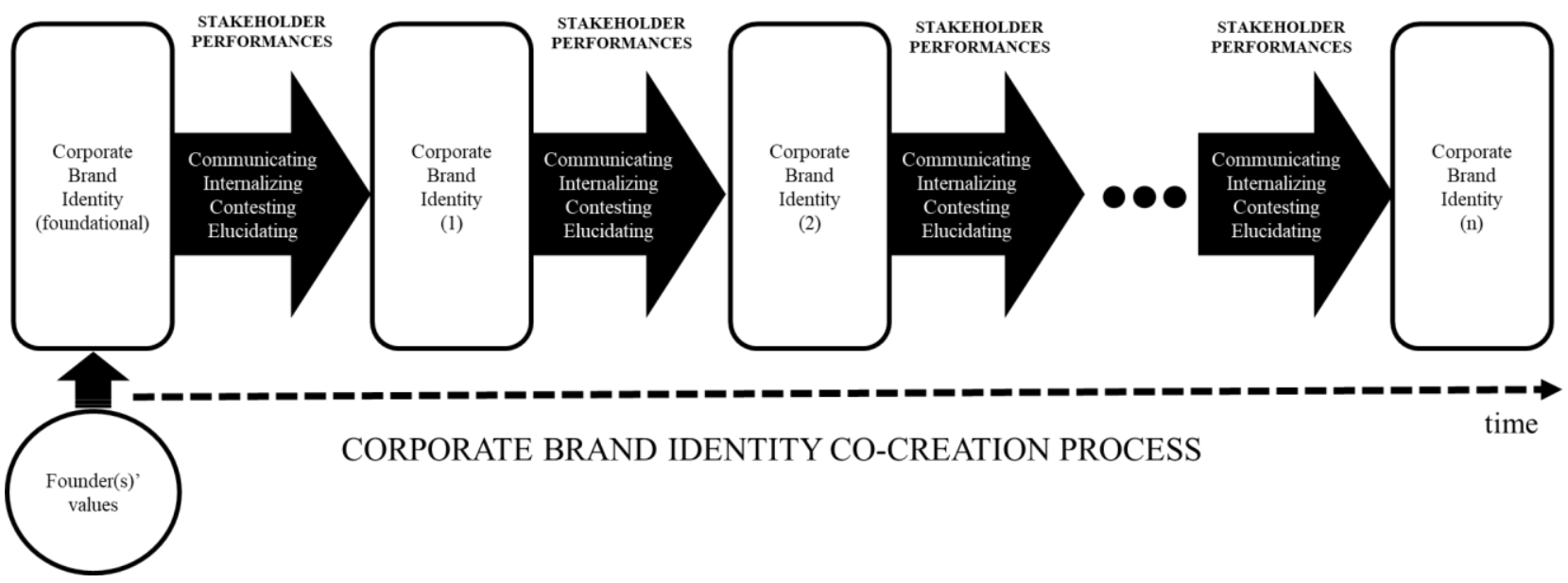


Appendix. Interview guide

Illustrative interview questions

- When did you start working at (the corporate brand)? Why?

- What does (the corporate brand) stand for? What are its values?

- How did (the corporate brand) come to be? What is its identity?

- What do you think is the major selling point of (the corporate brand)?

- What makes (the corporate brand) different from its competitors? How has this difference been built over time?

- Do you think that the different elements of (the corporate brand), such as its name, logo, colors or communications reflect (the corporate brand)'s identity well?

- Do you think that (the corporate brand) delivers on its promises, and to what extent?

- Do you speak about (the corporate brand) with other people? Would you recommend doing business with (the corporate brand)? Why?

Interviewer checklist of subjects covered

- Interviewee's definition and understanding of the corporate brand and the corporate brand identity concepts.

- The story about how the corporate brand and its identity were created, and evolved over time (including main internal and external stakeholders, and events).

- Description of the corporate brand identity at several points in time (if it changed).

- Specific internal and external stakeholder involvement in the corporate brand identity co-creation process, including the stage(s) and way(s) of involvement.

- Role of internal stakeholders in the corporate brand identity co-creation process.

- Role of customers in the corporate brand identity co-creation process.

- Role of other external stakeholders in the corporate brand identity co-creation process.

- Contextualization of the corporate brand with regard to industry, market, competitors...

- Remarks about the corporate brand and its identity in the B2B sector.

- Conclusion: Ask for anything else the interviewee wants to add or explain. 